\title{
Elastic dental prostheses - alternative solutions for patients using acrylic prostheses: Literature review
}

\author{
Zdzisław A. Bogucki ${ }^{1, A,-F}$, Mariola Kownacka ${ }^{2, A, B, D}$ \\ 1 Department and Division of Dental Prosthetics, Wroclaw Medical University, Poland \\ ${ }^{2}$ Resident, Department of Dental Prosthetics, Wroclaw Medical University, Poland \\ A - research concept and design; B - collection and/or assembly of data; $\mathrm{C}$ - data analysis and interpretation; \\ $D$ - writing the article; $E$ - critical revision of the article; $F$ - final approval of the article
}

Address for correspondence

Zdzisław A. Bogucki

E-mail:zdzislaw.bogucki@umed.wroc.pl

Funding sources

None declared

Conflict of interest

None declared

Received on January 26, 2017

Reviewed on March 9, 2017

Accepted on March 30, 2017

\begin{abstract}
Elastic dentures are prostheses made of thermoplastic material. This category includes: nylons, acetals, acrylic polymers, and acrons. Elastic prostheses have been recognized for several years; however, their properties are constantly being modified. In the opinion of the majority of patients, elastic prostheses are comfortable, handy and long-lasting. Elastic dentures are a good choice for esthetic reasons. They may be recommended for patients who do not accept clasps in framework dentures, but cannot afford dentures supported with precise elements or implant-based fixed appliances. Such dentures can be applied in masticatory organ rehabilitation in patients with increased absolute reflexes, especially retching. Furthermore, such features like size, construction weight or material plasticity and smoothness are considered to be advantages of thermoplastic materials. Elastic dentures are the only removable appliances for patients allergic to metal or acrylic. They are better tolerated by patients with an uneasy prosthetic base or with systemic diseases, e.g., diabetes, who are more susceptible to the traumatic activity of the hard plate of traditional dentures made of acrylic material. Adaptation time is shortened and the number of necessary corrections is reduced. Hygiene rules as well as follow-up visits terms must be strictly obeyed.
\end{abstract}

Key words: thermoplastic materials, elastic dental prostheses, antiallergic dentures

DOI

10.17219/acem/70044

\section{Copyright}

Copyright by Author(s)

This is an article distributed under the terms of the

Creative Commons Attribution Non-Commercial License

(http://creativecommons.org/licenses/by-nc-nd/4.0/) 
Elastic dentures are prostheses made of thermoplastic material. ${ }^{1}$ This category includes: nylons, acetals, acrylic polymers, and acrons. Elastic prostheses have been recognized for several years and their properties are constantly being modified. In the opinion of the majority of patients, elastic prostheses are comfortable, handy, esthetic, and long-lasting. ${ }^{2}$ This type of appliance is an alternative method in the rehabilitation of partially edentulous patients allergic to metals such as chrome, cobalt or nickel. ${ }^{3,4}$ They allow constructing elements supported on teeth with periodontal diseases and designing the plate in the case of inclined teeth requiring a deep approach. Elastic dentures are also less burdensome for patients with a gagging sensation or a retching problem. ${ }^{3}$ They are alternative solutions in the case of both small and more extensive gaps in patients with contraindications for acrylic dentures or in those who are allergic to acrylic. ${ }^{3-7}$ The application of thermoplastic materials in dentistry is very widespread. Elastic materials in dental prosthetics should have some very specific mechanical properties. ${ }^{2}$

Nylons are used mainly in partial dentures. Nylon is a synthetic polyamide resulting from the polycondensation of adipic acid and hexamethylenediamine. It is formed of fibers which can be divided into aliphatic, cycloaliphatic and aromatic ones. ${ }^{1,8,9}$ It undergoes condensation polymerization, and methacrylates undergo additional polymerization. ${ }^{10-13}$ Nylon is characteristic for its high elasticity, inflexibility, hardness, durability as well as mechanical strength. In comparison to metals, its mechanical strength and hardness are smaller. However, shape stability and fatigue strength as well as sliding properties, optimum abrasion resistance, strong suppression of vibrations, high impact resistance, good chemical resistance, low thermal expansion, good optic properties, coloration option, and the possibility to produce transparent objects are the main advantages of nylon.

In nylons, some organic solvents may provoke strain micro-cracks and the material has some confined compatibility when combined with acetals. It is relatively easy to treat mechanically (cutting, punching, milling). ${ }^{2}$ Dura-Flex (Myerson LLC, Chicago, USA) is one of the most popular elastic materials. It is a highly esthetic polyamide which gives the possibility to form the maximally thin construction at adequately preserved stability. ${ }^{14-16}$ Elastic materials used in prosthetic appliances are constantly being improved.

More advanced materials are characteristic for definitely smaller water absorbency, considerable resistance to color change, and bigger and stable stiffness, which enables the production of increasingly thinner appliances. They are also less translucent. Quite recently, Flex Star nylon has been introduced (Nobilium CMP Industries LLC, New York, USA), replacing the older generation nylon Valplast N1 10 (Valplast International Corp., New York, USA). ${ }^{14}$ However, Valplast and Flex Star have one common feature: their elasticity is enhanced at the increased temperature of the oral cavity, which distinguishes them among other nylon materials. This quality largely influences their use, denture construction design, the thickness of elements and plate, appliance range, and storage method (moisty environment is recommended). ${ }^{14,15}$

Acetals are used in supported dentures, elastic clasps and construction elements of other prosthetic devices. Acetal is a crystalline structure polymer with reduced residual monomer content and is a product of formaldehyde polymerization. ${ }^{10}$ It exhibits high resistance to wear, mechanical strength, perfect flexibility and elasticity, low thermal conductivity as well as adequate stiffness of the construction cores, and it can be sterilized at a temperature of $120^{\circ} \mathrm{C} .^{10-13,17}$ The material is available in many colors and shades; it does not form air bubbles even during the fabrication of very tiny elements. ${ }^{3}$ It is resistant to water, weak and strong alkalis, organic solvents such as paraffin hydrocarbons, alcohols, ethers, ketones, fuels, diesel oil, and fats. It has limited compatibility with nylon, high fatigue resistance, environment humidity resistance, size and shape stability at high temperatures, low friction coefficient in typical material combinations, high bacterial and fungal resistance, good sliding properties as well as very high rebound resilience. ${ }^{2}$ Acetals are divided into homo- and copolymers. Dental D (3M ESPE AG, Seefeld, Germany) is one of homopolymers which are products of worse physical and chemical properties in comparison with copolymers, e.g., DurAcetal (Myerson LLC, Chicago, USA). ${ }^{14}$ DurAcetal is used in the production of a variety of appliances, such as overdentures and snap-on overlays. In order to produce them, injection or scanning technologies are incorporated. Snap-on type overlays prove to be an expensive appliance used in the region of the maxilla and the mandible as well for pterygoid deficits in the mandible. They may be in the form of gaps, so they do not change the occlusal relations between the jaws. ${ }^{14-16}$ Acetal is also used in the production of stabilizing splints and space retainers as well as in the fabrication of protector pads for sportsmen.,

Acrylic polymers are a good material for complete dentures, crowns and temporary bridges. Polyvinyl resin (vinyl polymer) is a multi-particle substance, a mixture of vinyl acetate copolymers, which is elicited by vinyl monomers polymerization. Acrylic polymers are processed with the use of the injection method or hot stamping. Materials can be either translucent or in many colors. They are characteristic for their very low water absorption and the stability of color. ${ }^{10,12,18}$

Acrons are used in the production of complete or partial dentures. Acron is a thermoplastic material combining acrylic advantages (high luster) and polyamide excellence (fracture resistance and elasticity). Its melting temperature of $270^{\circ} \mathrm{C}$ assures that it is non-yielding in the oral cavity. ${ }^{19}$

All the above-mentioned materials are characteristic for their thick, non-porous internal structure, which prevents saliva penetration and the development of microorganisms, as well as for the manufacture technique based on plasticized material injection, and final extreme elasticity. $1,2,8,9,20$ 
A typical elastic denture is fabricated like an acrylic denture in respect to the initial clinical and laboratory stages. It is very important to qualify patients correctly for the appropriate method of denture fabrication. Acetal or nylon dentures cannot be applied in edentulous patients in whom adhesion force is mainly responsible for the denture support. ${ }^{10,11,18}$ There is no adhesion force between the bedding elastic dentures. In order to stabilize these dentures, thickening of the filling construction is necessary. In acetal dentures, modeled clasps should be thicker than in a traditional denture. Short and thick clasps have stronger fixation, whereas long and thin ones are more flexible. In turn, long clasps are recommended in very deep flanges, where traditional metal clasps are impracticable to use. In a traditional supported denture, construction adequate durability is attained at the plate thickness of $0.3-$ $0.5 \mathrm{~mm}$. In turn, acetal or nylon denture optimum thickness amounts to $1.5 \mathrm{~mm} .{ }^{1,9}$ Also, the fact that after years the structure of dentures remains resilient is considered an advantage of elastic materials. ${ }^{4}$ Elastic nylon dentures are also settling dentures. The nylon clasp arm contacts linearly with the tooth crown at the site of its most prominent bulge. With time, periodontal structures as well as abutment teeth are overpressed. In the case of elastic appliances construction, teeth flanges as well as alveolar process flanges can be either blocked or used in denture retention increase..$^{10,13,18}$ Conventional teeth-supported dentures are always shifted from the periodontium, whereas in the case of elastic ones it does not always happen. Sometimes, retention areas are incorporated to the denture fixation. Denture plate elasticity makes the appliance more prone to strain. Mastication forces do not strike denture balance, as there is no leverage force between the appliance sides. Mechanical damage like fractures or cracks is very rare.

However, the most important advantage of elastic appliances is no release of harmful monomer. In acrylic-based conventional appliances, mistakes that occur at the polymerization stage result in residual monomer release (1-2\%). ${ }^{1,6,8,9,21}$ Elastic materials are chemically inert and they do not provoke the formation of galvanic couples as it happens in the case of appliances based on metal construction. They do not provoke electro-metalloses, either. Apart from many other advantages, elastic materials are very esthetic. The colors of clasps made of these materials are similar to those of oral cavity tissues.

Thermoplastic materials, however, are not free from defects. Microbiological surveys show that Candida albicans and Staphylococcus aureus strains exhibit bigger affinity to nylon than to acrylic. The cases of slight inflammatory reactions in the areas of contact with mucous membrane have been reported. Besides, thermoplastic materials are more brittle due to a smaller tendency to deformations. ${ }^{1,4,10,17,20}$ Some disadvantages of thermoplastic materials may be reduced by the introduction of glass fibers. ${ }^{22}$ Glass fibers increase the strength of elastic materials, improve their bending strength and resistance to congelation. The content of $>50 \%$ of fibers in the mass base significantly influences the above-mentioned characteristics. ${ }^{22}$ The presence of $<10 \%$ of fibers in the denture composition does not change the physical properties. However, besides glass fibers content, their diameter is very important as well. Glass fibers elasticity modulus is close to this of the dentine. Acrylic polymers dentures reinforced with glass fibers prove stronger than prostheses devoid of them. ${ }^{22}$ Sometimes, unfavorable esthetic effects occur: nylon pellots visually shorten dental crowns and acetal clasps unnaturally thicken teeth.

The patient's correct classification and qualification for the particular type of appliance is very significant, and among many criteria there are: adequate prosthetic basis (it cannot be loose), dental gaps arrangement (partial gaps are mostly favorable). ${ }^{14-16}$ The treatment should always be preceded by compiling the medical history and performing a clinical investigation of the patient. Also, diagnostic impressions can be taken or, on the basis of elicited information, conservative, surgical and periodontology treatment may be instituted. ${ }^{14}$ The recognition of the physical and chemical parameters of the materials is very important as well.

The difference between conventional and elastic dentures concerns mainly the laboratory stage of fabrication. After taking individual impressions, a provisional cast is made of plaster class IV and occlusal patterns are performed in it. It is very important to duplicate the models (with the use of silicone and plaster class IV and of $1.5 \%$ expansion). ${ }^{14,19}$ Avoiding this procedure may result in inexact adhesion or excessive activity of retention elements pressure, which gives the sensation of a "too tight" denture and requires numerous corrections. In the case of a complete denture made of acron, flanges are not blocked in the model. Elastic dentures are modeled on a duplicated mould.

First, the technician patterns the framework of the elastic denture of the mould wax. In the case of acron dentures, the plate should reach the tooth preparation margin. ${ }^{19}$ In the case of partial, elastic supported dentures, the model paralelometric evaluation should be performed, flanges should be partially blocked and crevices relieved. The model is placed in a special container and injections canals are formed. Unskillful formation, avoiding the use of the protection mass for thermoplastic materials as well as inobservance of material hardening times cause many imprecisions. ${ }^{14}$ The material is introduced to the container using the thermal injection method. It is melted and subsequently pressurized; the manufacturer's recommendations are absolutely important while the melting temperature, injection time and pressure are defined on the injection moulding machine panel. This technique is difficult and requires maximum accuracy. The procedures of material heating, pressure increase, injection force control, and cooling time keeping should be watched. Disobedience of the above-mentioned procedures results in air bubbles trapped in thermoplastic material, teeth loss, teeth occlusion shift, plate adhesion incorrectness or too small amount of injected material 
in peripheral regions. ${ }^{14}$ After releasing denture medium from the container, it is modeled and adjusted to the mould so that it has appropriate thickness and shape. On the prepared framework of the elastic denture, teeth are positioned. Teeth are positioned in a laboratory on the basis of the information registered by the dentist after elastic prosthesis framework elaboration. Acron does not bond chemically with acrylic teeth, so each tooth must be prepared individually, crow step milled and openings at the tooth basis drilled. Correct preparation is a solid warrant of the tooth stability in an acron plate. ${ }^{19}$ It is important to position teeth of good quality and low abrasiveness, avoid flat-cuspid ones used in the Wrocław method of fabrication of extensive dentures. At subsequent stages, the technician carries out canning and polymerization, perfects and polishes the ready denture, and controls adhesion accuracy on the diagnostic mould. Thermoplastic materials should not be cut and heated again, as it causes denture fragility, water increased absorption and material staining. ${ }^{14}$ Final refinement of elastic dentures constitutes a big problem. It requires a special technique based on the abrasion materials which are not cutting. The use of inappropriate instruments decreases the quality of appliances quality by the formation of micro scratches. Polishing at an increased temperature causes melting and softening of the material, especially nylon. All the above-mentioned errors cause a decrease in esthetics and staining. The correction of elastic dentures requires the "short-term goals" rule. Polymers and nylons dentures are corrected using a low speed. For this purpose, the stones are white or green with a diamond coating. ${ }^{14-16}$ Polishing should be carried out at low rotation with the use of hard rubber tips and Scotch-Brite micro discs or Habra's abrasion discs as well as Marvel and Flexi-Brites type preparations. ${ }^{14}$

Acetal dentures are corrected with sharp mills designed for acrylic. In the case of vast corrections, plaster mill provides good results, whereas small errors can be corrected with diamond-coated stones, hard rubber tips and sometimes carborundum stones. Polishing is achieved with the use of hard rubber tips and polishing systems (e.g., Marvel, Scratch remover CDM Dental). Their disadvantage is a limited possibility of modification after denture completion, e.g., widening the prosthetic field after teeth extraction. A new tooth can be positioned only close to the acrylate plate. ${ }^{3,14}$ Furthermore, improper preparation of teeth while settling them in the denture saddle during the laboratory process may make the retention areas susceptible to dental plaque. Humid environment of the oral cavity favors fungal colonization, mainly Candida albicans, which occur in the normal flora of the mouth, but they remain in the biological equilibrium. Any imbalance of this condition triggered by improper hygiene or material porosity favors the development and spread of bacteria and fungi. ${ }^{4,23}$ In conventional dentures, after acrylic surface silanizing, Candida albicans - appliance adhesion drops significantly. Also, material to water affinity decreases and the mechanical strength of dentures grows. ${ }^{4,23}$ Hygiene is especially important in using elastic dentures. As in the case of conventional appliances, special means for cleaning elastic dentures have been elaborated and they are manufactured by pharmaceutical laboratories. ${ }^{14}$ Preservatives ProTech and Smile Again (Boynton Beach, USA) are recommended. They also prove applicable in acrylic appliances, especially those in which soft materials are incorporated as liners, retainers or hard-soft materials in splints.

Apart from their long-term application, thermoplastic materials have auxiliary employment in temporary appliances, both permanent and removable.

FJP (Pressing Dental, San Marino) is one of the representatives of copolymers. Its resilience degree positions this material between acetals and nylons. It can be used for the fabrication of partial dentures, along with retention elements, esthetic pellots or clasps and occlusal support. It is free from many disadvantages of thermoplastic materials, especially their unfavorable influence on the prosthetic base, and it is easier in mechanical treatment. FJP appliances may be repaired and subsequent teeth may be added to the denture, as this material combines with acrylic. It is mainly incorporated in temporary appliances or provisional dentures. Due to its hypoallergenic properties, it may replace acrylic in framework dentures in patients sensitive to acrylic material. ${ }^{7,24,25}$

Luxaform (DMG Chemisch-Pharmazeutische Fabrik $\mathrm{GmbH}$, Hamburg, Germany) is another thermoplastic material applied in fixed temporary prosthetic appliances. It is an alternative solution in provisional tasks performed directly after impression making. ${ }^{26}$ It reduces the time of prosthetic appliance fabrication, as the dentist, ex tempore, makes the matrix of Luxaform before the tooth preparation. This polymer (polycaprolactone), at room temperature is found in the form of blue non-translucent tablets. They are plasticized while heating in water at a temperature of $70^{\circ} \mathrm{C}$ for $1-2 \mathrm{~min}$ or in a microwave oven in $1 / 4$ glass of water for $1 \mathrm{~min}$.

When the material is already plastic, it should be spread over the tooth waiting to be prepared as well as over the adjacent teeth from the mesial and distal sides, and pressed firmly. Then, the whole area should be dried with air until there is opacity and color. Further steps in the procedure of the fabrication of temporary fixed appliances are similar to those of the impression taking method. However, acrylic should not be applied to the matrix, as it bonds both thermally and chemically with Luxaform. For this reason, the following composite materials are recommended: Luxatemp (DMG Chemisch-Pharmazeutische Fabrik GmbH), Protemp 3 Garant (3M ESPE AG, Seefeld, Germany), Provitemp K (Bisico Bielefelder Dentalsilicone GmbH \& Co. KG, Bielefeld, Germany).

Luxaform (DMG Chemisch-Pharmazeutische Fabrik $\mathrm{GmbH}$ ) is also very useful while constructing the splint, which follows the positioning of an implant during the implantation procedure in accordance with the "simple in practice" routine. ${ }^{26}$ 
It may be an alternative if there is no laboratory splint at disposal or in emergency cases during implantological treatment.

Elastic thermoplastic materials are increasingly common in dentistry. However, their disadvantages should always be recognized and kept in mind. In planning complex treatment, all available prosthetic methods should be considered, including elastic dentures, which ought to be confronted with conventional appliances.

Elastic dentures are a good choice for esthetic reasons. They may be recommended for patients who do not accept clasps in framework dentures, but cannot afford dentures supported with precise elements or implant-based fixed appliances. Such dentures can be applied in masticatory organ rehabilitation in patients with increased absolute reflexes, especially retching.

Moreover, such features as size, construction weight, material plasticity and smoothness are considered the advantages of thermoplastic materials. Elastic dentures are the only removable appliances for patients allergic to metal or acrylic. They are better tolerated by patients with an uneasy prosthetic base or with systemic diseases, e.g., diabetes, i.e., more susceptible to the traumatic activity of the hard plate of traditional dentures made of acrylic material. The adaptation time is shortened and the number of necessary corrections is reduced. Hygiene rules as well as follow-up visit terms must be strictly obeyed.

\section{References}

1. Marcińczyk A, Hołownia K. Protezy termoplastyczne: Placebo czy panaceum? TPS. 2011;10:50-54.

2. Niedzielska I, Fakhari R, Czerniecki P. Współczesne systemy wykonywania protez elastycznych w praktyce. Część I. As Stomatol. 2006;3-4:36-40.

3. Stwora I, Karski L, Karska B. Acetal-proteza z wyboru. TPS. 2012;11:30-32.

4. Al-Akhali MA, El-Kerdawy MW, Ibraheim ZA, Abbas NA. Comparative study on the microbial adhesion to acetal resin and metallic removable partial denture. Indian J Dent. 2012;1:1-4.

5. Staroń-Irla K, Zalewska I. Rehabilitacja protetyczna pacjenta z zastosowaniem protezy acetalowej: Opis przypadku. TPS. 2011;6:46-48.

6. Lekha K, Savitha NP, Roseline M, Nadiger K. Acetal resin as an esthetic clasp material. J Interdiscip Dentistry. 2012;2:11-14.

7. Pilich J. Zastosowanie termoplastycznego kopolimeru FJP do wykonania protezy tymczasowej. Mag Stomatol. 2016;10:26-28.

8. Fakhari R. Różnice systemowe w technologii tworzyw termoplastycznych. Nowocz Tech Dent. 2008;3:44-46.

9. Kasperski J, Wyszyńska M, Jaroszuk-Rogal M, Mitera A. Protezy acetalowe i nylonowe: Przegląd piśmiennictwa. Mag Stomatol. 2010;2:26-29.

10. Mamczur J, Czelej-Piszcz E, Kamińska A, Szalewski L, Borowicz J, Rutkowski A. Materiały termoplastyczne w protetyce stomatologicznej. Mag Stomatol. 2015;7-8:102-109.

11. Pihut M, Wiśniewska G. Zagadnienia biokompatybilności i osteointegracji we współczesnej protetyce. Prot Stomatol. 1996;46(1):28-32.

12. Körholz KH, Mikuš M. Rewolucja w tworzywach akrylowych: Nowa generacja sztucznych żywic na bazie PMMA. Nowocz Tech Dent. 2009;2:37.

13. Łojszczyk R. Praca z materiałem termoplastycznym. Nowocz Tech Dent. 2012;4:40-48.

14. Polanowski K. Protezy elastyczne i wykorzystanie technologii tworzyw termoplastycznych w praktyce stomatologicznej. Mag Stomatol. 2013;4:70-78.

15. Skalak R. Biomechanical consideration in osseointegrated prostheses. J Prosthet Dent. 1983;49(6):843-848.
16. Singh JP, Dhiman RK, Bedi RPS, Girish SH. Flexible dentures base materials: A viable alternative to conventional acrylic dentures base material. Contemp Clin Dent. 2011;2(4):313-317.

17. Rutkowski A, Połczyńska M. Ruchomy utrzymywacz przestrzeni wykonany z zastosowaniem żywicy acetalowej cz. II. Nowocz Tech Dent. 2012;3:50-56.

18. Rutkowski A. Acetal: Estetyczna alternatywa rozwiązań protetycznych. Nowocz Tech Dent. 2007;4:35-39.

19. Pradiuch K. Protezy z acronu: Ekonomiczna alternatywa dla protetyki estetycznej. Twój Prz Stomatol. 2014;9:106-112.

20. Bartczyszyn M, Janczewski M, Tomalik I. Protezy ruchome nylonowe: Alternatywa dla protez akrylowych w leczeniu protetycznym. Mag Stomatol. 2007;17(9):38-42.

21. Sikorska-Bochińska J, Urbanek R. Elastyczne i sprężyste tworzywo na protezy ruchome i stałe $w$ aspekcie alergii kontaktowej. Nowe uzupełnienia protetyczne w stomatologii - Acetal Pressing Dental. Twój Prz Stomatol. 2005;5:32-34.

22. Nagakura M, Tanimoto Y, Nishiyama N. Fabrication and physical properties of glass-fiber-reinforced thermoplastics for non-metal-clasp dentures. J Biomed Mater Res B Appl Biomater. 2017;105(8):2254-2260.

23. Yodmongkol S, Chantarachindawong R, Thaweboon $\mathrm{S}$, et al. The effects of silane- $\mathrm{SiO}_{2}$ nanocomposite films on Candida albicans adhesion and the surface and physical properties of acrylic resin denture base material. JPD. 2014;122(6):1530-1538.

24. Rutkowski A. F.J.P. - kolejny krok w termoplastyce. Nowocz Tech Dent. 2009;3:25-27.

25. Rutkowski A. Materiał termoplastyczny F.J.P. po kilkuletnim użytkowaniu. Nowocz Tech Dent. 2014;1:32-36.

26. Pietruski JK, Pietruska MD. Wykorzystanie materiału Luxaform w protetyce. Protet Stomatol. 2006;56(3):238-242. 